\title{
The Embellishment of Bottom Line through Hyperbole of Accrued Earnings: A Case of Deliberate Earnings Management of a Non-bank Financial Institution Enlisted in Dhaka Stock Exchange and Chittagong Stock Exchange
}

\author{
Md. Thasinul Abedin ${ }^{1}$ \\ ${ }^{1}$ Graduated from Accounting \& Information Systems, University of Dhaka, Dhaka-1000, Bangladesh \\ Correspondence: Md. Thasinul Abedin, Graduated from Accounting \& Information Systems, University of Dhaka, \\ Dhaka-1000, Bangladesh.
}

Received: November 14, 2016

doi:10.11114/bms.v2i4.2009

\author{
Accepted: November 21, 2016 \\ Online Published: November 24, 2016 \\ URL: http://dx.doi.org/10.11114/bms.v2i4.2009
}

\begin{abstract}
The study has tried to find out the key parameters through which a non-bank financial institution can embellish its earnings. The study has found that loan loss provisions increases in line with the increase in loan and advances and interest suspense. Moreover, non-bank financial institutions always report other assets except accounts receivable figure which foreshadows an existence of deliberate inflation of earnings. The study has found a positive impact of total loan loss provisions and interest suspense on accrued income, a clear message that non-bank financial institutions always report more accrued earnings to safeguard their profit. Increase in accrued income in line with total loan loss provision and interest suspense is also validated by increase in accrued income with respect to other assets except accounts receivable figure even though the impact of other assets on accrued income is insignificant at 5\% level, an accounting channel through which excess other assets except accounts receivable would be inflated for excess increase in accrued income. The study has deduced that other assets except accounts receivable is a reserve bank for discretionary inflation of earnings even though it is insignificant. The study has used time series monthly data of International Leasing and Financial Services Limited, a non-bank financial institution from 2009-2015 reported in the Statement of NBDC sent to Bangladesh Bank each month. Two-time series models have been used in this study. The first model has tried to find out the impact of loan and advances, interest suspense, and other assets except accounts receivable on total loan loss provision. In the first model, there is a significant impact of loan and advances, interest suspense, and other assets except accounts receivable on total loan loss provision. The second model has tried to discern the impact of total loan loss provision, interest suspense, and other assets on accrued income along with other independent variables namely-loan and advances, total fixed assets, and operating income. The study has found a significant positive impact of total loan loss provision and interest suspense on accrued income and insignificant impact of other assets except accounts receivable on accrued income. For both models, there is no long-run relationship among the variables.
\end{abstract}

Keywords: non-bank financial institutions, earnings, loan-loss provision, loan and advances, other assets except accounts receivable, total fixed assets, operating income, statement of NBDC, and Bangladesh bank

JEL Classification: C01, C12, C13, and C32

\section{Introduction}

Earning, occasionally called "the bottom line" or "net income", is the single most vital item in financial statements. They include the extent to which a company has engaged in value-added activities. They work as a signal that helps direct resource allocation in capital markets. In fact, theoretical value of a company's stock is the present value of its future earnings. Increased earnings represent an increase in company value, while decreased earnings signal a decrease in that value ${ }^{1}$. Given the importance of earnings, it is no surprise that company management has a vital interest in how they are reported. A company can manage its earnings in two ways- legal earnings management and illegal earnings

\footnotetext{
${ }^{1}$ Lev, B. (1989), On the usefulness of Earnings and Earnings Research: Lessons and Directions From Two Decades of Empirical Research, Journal of Accounting Research, Vol.27, pp.153-201
} 
management. Legal earnings management may be defined as reasonable and legal management decision making and reporting to achieve stable and predictable financial results. Legal earnings management should not be confused with illegal way of earnings management. Even though earning management is not always bad, illegal way of managing earning to deceive shareholders is not acceptable. Many authors have come into the conclusion that companies usually manage earnings to cover their poor performance and deceive investors and stakeholders (bondholders). Managers also manage earnings to increase their incentive, a case of agency conflict. Schipper (1989) defined earnings management as "...a purposeful intervention in the external financial reporting process, with the intent of obtaining some private gain (as opposed to, say, merely facilitating the neutral operation of the process)." Managers may manage earnings for the contractual outcomes also. Healy and Wahlen (1999) said: "Earnings management occurs when managers use judgment in financial reporting and in structuring transactions to alter financial reports to either mislead some stakeholders about the underlying economic performance of the company, or to influence contractual outcomes that depend on reported accounting numbers." While most corporate executives respect investors and shareowners and report in accordance with the standards, there is always the risk that some executives might misrepresent financial data for achieving contractual outcomes (Kellogg, 1991).

An extreme form of earnings management, fraudulent earnings management, is well defined as: "the intentional, deliberate, misstatement or omission of material facts, or accounting data, which is misleading and, when considered with all the information made available, would cause the reader to change or alter his or her judgment or decision. (National Association of Certified Fraud Examiners, 1993). Callao and Jarne (2010) argued that accounting standards can restrain managers' ability to misrepresent accounting numbers. Where inflexible and rigid accounting rules that offer limited accounting options can restrict the scope for subjective judgments, which can in turn constrain managers' ability to behave opportunistically. Many executives face a lot of pressure to deliberately manage earnings. "A 1998 survey at a conference sponsored by CFO Magazine found that 78 percent of the Chief Financial Officers (CFOs) in attendance had been asked to cast financial results in a better light, though still using Generally Accepted Accounting Principles (GAAP). Half of them complied with the request. However, 45 percent of the group attendees reported that they had been asked to misrepresent their financial results- and 38 percent admit with complying. The intense pressure to report better earnings was confirmed by a similar survey at a Business Week CFO conference. It has been found that 55 percent of the CFOs had been asked to misrepresent financial results, and 17 percent had complied"2. The agency concept stresses the complexities that can arise under conditions of asymmetric and incomplete information, between the principal and the agent. As it can result in agency concerns, which are namely issues that occurs when these two parties, have different interests. In this context, agents may have incentives to undertake actions and make decisions that are not in line with owners' interests, when preparing the financial information (Fama, 1980; Fama\& Jensen, 1983).

Banks and other financial institutions are often excluded from earnings management research because their characteristics differ fundamentally from other firms (Peasnellet al., 2000). To mention a few authors, Meisel (2013), Duru and Tsitinidis (2013), Ahmed et al. (1999), Anandarajanet al. (2007), Bhat (1996), Barth et al. (1995), Beatty et al. (1995), Kim and Kross (1998), Moyer (1990), Beaver et al. (1989), Scholes et al. (1990), Wahlen (1994), Beaver and Engel (1996), and Liu and Ryan (2006) etc. have conducted research on earning management in financial companies like banks. This study has tried to detect deliberate earning management in financial sector especially in non-bank financial institutions by addressing two key issues-whether increase in loan and advances and interest suspense increases the total loan loss provision? And whether increases in total loan loss provision and interest suspense increases the accrued interest income? It is very common that the financial institution may compensate the excess provision and interest suspense by reporting higher accrued interest income. It may be true that the company may increase the other assets except accounts receivable figure to report more accrued interest income. To be ensured whether increase in other assets except accounts receivable figure increase the accrued income, the second model has been used. Conclusion has been drawn based on GLS results. In the model development section, justification has been given behind the development of the models.

\section{Objectives, Methodologies, Limitations, and Rationale of the Study}

\subsection{Objectives of the Study}

This study has tried to answer a few questions- whether deliberate earnings management presents in financial sector comprising non-bank financial institutions or not? Whether totals loan loss provision increases with respect to increase in loan and advances and interest suspense? How firms may report better bottom line even though it has high loan loss provision and interest suspense? Whether a firm increases the other assets figure except accounts receivable (as reserve bank) with respect to increase in accrued interest income? This study attempts to identify a new way of deliberate

${ }^{2}$ Earnings Management, p.1.http:/www.romeassoc.com/inv_lit/archives/earnings.htm. [Accessed July 3,2016] 
earnings management in non-bank financial institutions that has not attracted too much attention before in Bangladesh. Hence, from the perspective of non-bank financial institutions, this paper is an excellent contribution in a new way of deliberately managing earnings.

\subsection{Methodologies and Limitations of the Study}

The study is completely based on quantitative research methods-OLS and GLS. Since time series data set has been used, stationary checking has been performed by using the Augmented Dickey Fuller (ADF) test with and without trend. The study has also checked - whether long- run relationship exists among the financial variables. There is no long-run relationship among the variables. Hence, causality has not been checked even though time series data have been used. After diagnostic tests (namely auto-correlation and heteroscedasticity) in OLS, the GLS result has been used for final conclusion and decision making.

As the study is completely based on time series data of a single non-bank financial institution - International Leasing And Financial Services Limited (Inductive Research) enlisted in Dhaka and Chittagong Stock Exchange, it is very tough to generalize the results into the entire financial sector comprising non-bank financial institutions. Also the results generated from the two models will only remain in the short run. Therefore, considering the long term prospects, the result may be insignificant for long-term planning and decision making. Due to lack of data, monthly data have been used.

\subsection{Rationale of the Study}

As a large contributing sector to the GDP of Bangladesh, financial sector carries more importance and prioritization. From 2000 to 2009, financial sector's non-performing loan to total loan and advances ratio was excessively larger than financial sector's capital to assets ratio. Even though financial sector's poor performance (having higher non-performing loan to total loan and advances ratio than capital to assets ratio), financial sector experienced some profit margin (Net profit to total loan and advances ratio).

Therefore, a question automatically comes in that, whether financial sector actually is receiving profit or loss or simply reporting high profit?

Since Bangladesh as a developing country lies in frontier economies domain (possessing weak legal system, politically manipulated market, and low per capita income), the flow of information financial sector is not that much smooth between the concerned parties unlike the developed countries. As a result a common concern usually arises, whether the depositors providing mainstream funding source to the financial sector consisting of banks and non-bank financial institutions are getting the actual scenario of financial sector performance?

This study has tried to answer whether financial sector is reporting actual profit or simply boosting its bottom line.

The mean non-performing loan (NPL) to total loan and advances from 2000 to 2004 is $26.82 \%$ (Source: Bangladesh Bank) and from 2005 to 2009 is $13.56 \%$ (Source: Bangladesh Bank). The mean capital to assets ratio from 2000 to 2004 is $3.72 \%$ (Source: Bangladesh Bank) and from 2005 to 2009 is 5.51\% (Source: Bangladesh Bank). Both scenarios are getting improved gradually. The question is -is it truly happening in the financial sector consisting of non-bank financial institutions? Profit to total loan and advances ratio is getting improved gradually. In fact, there is accelerating growth in profit to total loan and advances ratio from 2000 to 2009. The average growth rate of non-performing loan from 2006-2013 is 12.50\% (Source: Bangladesh Bank), average growth rate of net profit from 2006 to 2013 is $18 \%$ (Source: Bangladesh Bank), and average growth rate of total loan and advances is 17.8\% from 2006-2013 (Source: Bangladesh Bank). Here it is clear that total loan and advances are increasing at a higher rate than non-performing loan. The reason behind it might be financial institutions are lending at an increasing rate to highlight lower non-performing loan to total loan and advances ratio. Another reason behind the study is that the relationship found among NPL and profitability is mixed. Tsai and Huang (1999) examined the relationship between management quality and cost efficiency within Taiwan's banking industry. They discovered that asset quality and cost efficiency are related; the non-value-added activities of bad assets incur a negative consequence on the operating performance. However, Fan and Shaffer (2004) analyzed profit efficiency of large commercial banks in the U.S. by accounting for non-performing loans. They found that, although non-performing loans are negatively related to banks' profit efficiency, it is not statistically significant. Vatansever and Hepsen (2013) showed that the Return on Assets has positive impact on NPL. Kithinji (2010) found that bulk of profits of commercial banks are not influenced by the NPL.As a key sector to contribute in GDP, this study will also reveal whether financial sector is deliberately working to overstate the GDP or not. This study will also help the regulators, to rigidly monitor the entire financial system so that true and fair information could be provided to the stake-holders (mainly the depositors).

Another two crucial reasons to conduct this study are non-bank financial institutions usually collect deposits from public. Therefore, financial institutions deal with public money. If a financial institution having poor financial 
performance reports extraordinary performance to stakeholders (mainly depositors) to collect deposit, it may question the financial position of that institutions and increase financial distress in the long run and it was generally observed that undesirable banking practices such as poor risk diversification, inadequate loan evaluation, fraudulent activities were as much responsible as other macroeconomic factors in causing baking crises that shook the financial systems of nations (Arun and Reaz, 2005).

\section{Review of Literatures}

A number of studies have been found on earnings management conducted on financial and non- financial sectors. As for example, banks can use accruals to manage their earnings (e.g., Beaver et al., 1989; Moyer, 1990; Scholes et al., 1990; Wahlen, 1994; Beatty et. al, 1995; Beaver and Engel, 1996; Kim and Kross, 1998; Liu and Ryan, 2006). Loan loss provision is a common accrual item for financial companies. For classified loans, it is inevitable to keep provision. Beaver et al. (1996) and Labo and Yang (1996) found that loan-loss provisions are used mainly in three types of discretional practices-to smooth income, to manage capital, and to signal financial strength.

Therefore, due to existence of loan loss provision, the company may use it as earnings management tool. Researchers found the mixed results whether loan loss provision is used as a earnings management tool. For example, Greenawalt and Sinkey (1988), Wahlen (1994), Laeven and Majnoni (2003), and Liu and Ryan (2006) found that when earnings are unusually high, banks can choose discretionary earnings-reducing loan loss provision whereas when earnings are unusually low loan loss provision can be deliberately understated or loan loss allowances can be released to offset operational losses. In studies by Greenawalt and Sinkey (1988) and Ma (1988) it was concluded that banks used loan loss provision as long-term mechanisms to smooth earnings. In these studies, total loan loss provision was used as the dependent variable. Greenawalt and Sinkey (1988) focused on the behaviour of loan loss provision as a function of banks' income and other measures of business conditions that are likely to affect the quality of loan portfolios. Ma (1988) showed that loan loss provision is actually not strongly related to the actual quality of loan portfolios, but that management tends to raise loan loss provision in periods of high operating income and vice versa.

There are also studies that found evidence that banks do not use loan loss provision as an earnings management tool. These studies have been conducted by Wetmore and Brick (1994), Beatty et al. (1995), and Ahmed et al. (1999). Beatty et al. (1995) found only a small statistic relation between earnings and loan-loss provision, providing virtually no evidence that loan loss provisions are used to manage earnings. Ahmed et al. (1999) found that earnings management is not an important driver of loan loss provisions, but that loan loss provisions reflect meaningful changes in the expected quality of banks' loan portfolios. Anandarajan et al. (2005) concluded that the results of the different studies on earnings management through manipulation of loan loss provision are conflicting. In this regard, Fonseca and González (2008) provide a panel study of 40 countries (excluding the United States) and find that neither the amount of income smoothing using loan loss provisions nor the difference in income smoothing using loan loss provisions between public and private banks is stable across countries. Kim and Kross (1998), Ahmed et al.(1999), and Bikker and Metzemakers (2005) found that banks keep higher provisioning when capital is low indicating capital and provisions are substitutable. However, some studies (Davis and Zhu, 2009; Craig et al., 2006; Bishop, 1996; Collins et al., 1995) fail to find a link between bank capitalization and loan loss provisioning.

Since loan loss provision behavior is subject of substantial debate in current banking literatures (Koch and Wall, 2000 and Benston and Wall, 2005) and Still no one has studied whether financial institutions specially non-bank financial institutions are deliberately overstating accrued income for increase in loan loss provision and they are keeping those accruals in the other assets figure (an accounting channel through which other assets would be debited for the opposite credit entry of the accrued income). This study has tried to justify the overstatement in accrued income as a result of the increase in total loan loss provision by the increase of total loan and advances (in the first model) by subsequently using a second model where the second model will show increase in total loan loss provision will increase the accrued income to protect the consistently stable bottom line (the net income or earnings). The study has been conducted on non-bank financial institutions for the first time in Bangladesh. Traditional econometric tools and techniques namely OLS and GLS have been used in this study. This study attempts to identify a new way of deliberate earnings management in non-bank financial institutions that has not attracted too much attention before in Bangladesh. Hence, from the perspective of non-bank financial institutions, this paper is an excellent contribution in a new way of deliberately managing earnings.

\section{Formulation of Hypotheses, Development of Model, and Defining the Variables}

Healy (1985) and De Angelo (1986) were the pioneering scholars in earnings management literature. However, the biggest impact in this field belongs to Jones (1991). Her model has been changed with some modifications by the descending studies such as modified Jones model of Dechowet al. (1995), and performance matched discretionary accrual model of Kothari et al. (2005). Healy and Wahlen (1999) state that these models use aggregate accruals 
approach, meaning that they try to test earnings management over total accruals. These studies generally focused on non-financial companies and industries. It should be kept in mind that the nature of financial companies is completely different from non-financial companies. The revenue generating assets of financial companies are different from those of nonfinancial companies. For example, the key revenue generating assets in financial companies are loan and advances where property, plant, and equipment are the key revenue generating assets in non-financial companies. It is notable that financial companies are vulnerable to the key changes in macro-economic variables. Therefore, financial companies always try to manage earning in a stable level.

Several studies found conclusive evidence that loan loss provisions are used for managing earnings (Greenawalt and Sinkey, 1988; Wahlen, 1994, Laeven and Majnoni, 2003; Liu and Ryan, 2006). In studies by Greenawalt and Sinkey (1988) and Ma (1988) it was concluded that banks used loan loss provision as long-term mechanisms to smooth earnings. In these studies, total loan loss provision was used as the dependent variable. Greenawalt and Sinkey (1988) focused on the behavior of loan loss provision as a function of banks' income and other measures of business conditions that are likely to affect the quality of loan portfolios. Ma (1988) showed that loan loss provision is actually not strongly related to the actual quality of loan portfolios, but that management tends to raise loan loss provision in periods of high operating income and vice versa. This has also been found by Collins et al. (1995) and Kanagaretnam et al. (2004).

“...banking supervisors love the loan loss reserve. When used as intended, it allows banks to recognize an estimated loss on a loan or portfolio of loans when the loss becomes likely, well before the amount of the loss can be determined with precision and is actually charged off. That means banks can be realistic about recognizing and dealing with credit problems early, when times are good, by building up a large „war chest ${ }^{\text {te }}$ of loan loss reserves. Later, when the loan losses crystallize, the fortified reserve can absorb the losses without impairing capital, keeping the bank safe, sound, and able to continue extending credit (Dugan, 2009)".

So far the authors mentioned above used the total loan loss provision as dependent variable and the models used in the above mentioned literatures said that financial institutions can increase or decrease loan loss provisions to have less volatility in profitability of the banks. In this regard, financial institutions can be very much conservative during the peak periods and aggressive in the bad periods.

Robb (1998) also studied whether bank managers manipulate earnings to meet market expectations about profitability or not. The result of the study shows that discretionary accruals are important to meet market expectations. On the other hand, the way of performance measurement is also important for getting reliable financial information in banks.

Still not a single literature especially on Bangladesh financial sector comprising non-bank financial institutions has shown that a financial institution can overstate its accrued interest income to protect the bottom line for increase in loan loss provision and interest suspense account balance. Also non-bank financial institutions may increase other assets figure for increase in accrued interest income. In one sense it is deliberate way of performance measurement. Therefore, how banks and non-bank financial institutions measure performance (Robb, 1998) can play a role in reporting better performance. This study has tried to fill up the gap especially on non-bank financial institutions' reporting. In this regard to fill the gap, the study has thrown a few questions and subsequently answered the questions with the help of econometric tools and techniques-

Whether total provision increases with the increase in total loan and advances and interest suspense account balance?

If total provision increases with the increase in total loan and advances and interest suspense account balance does the firm report more accrued interest income to protect the net profit?

Does the firm increase other assets except accounts receivable for increase in accrued income where increase in other assets with respect to increase in accrued income in an accounting treatment?

Therefore, based on the above questions, the required hypotheses will be-

$\boldsymbol{H}_{1}$ : Increase in total loan and advances and interest suspense account balance increase total loan loss provision.

$\boldsymbol{H}_{2}$ : Firms report more accrued interest income for increase in total loan loss provision and interest suspense account balance

$\boldsymbol{H}_{3}$ : The firms report more other assets except accounts receivable for increase in accrued interest income, an accounting treatment. 


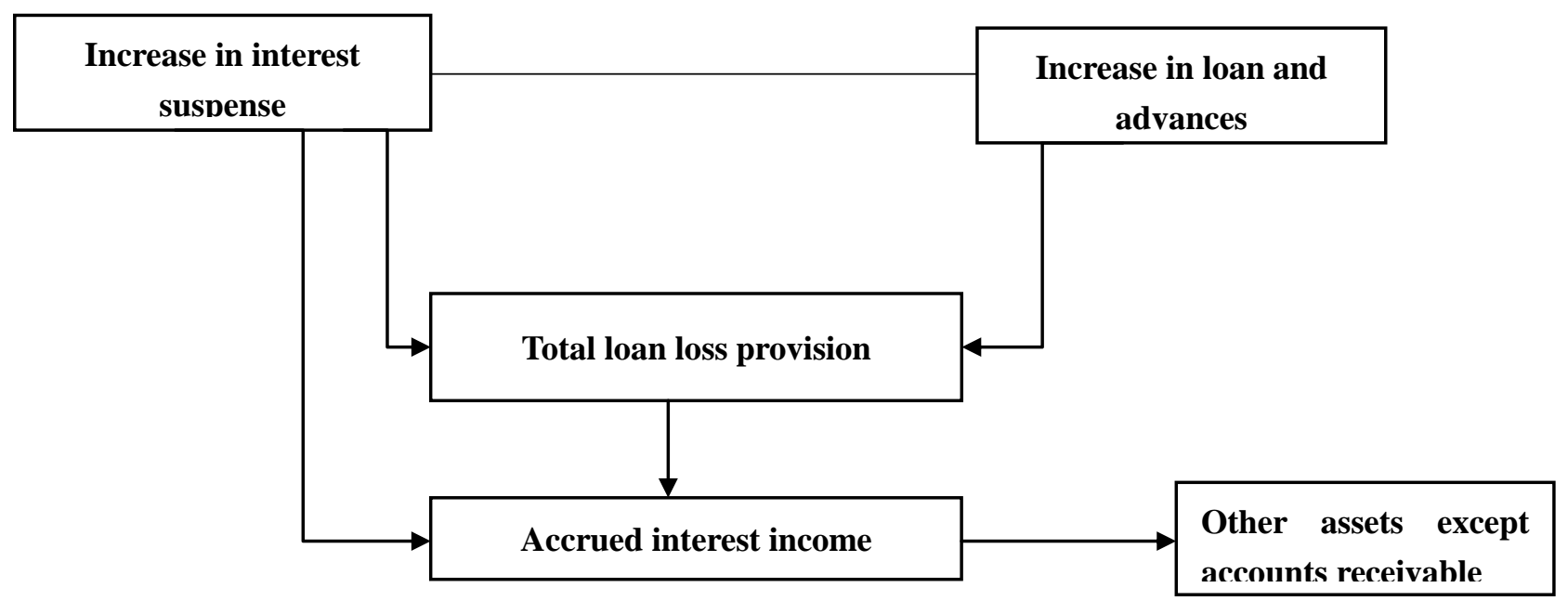

Figure 3. Hypothetical figure based on three hypotheses. The symbol $(\rightarrow)$ denotes increase

To prove the hypotheses, two-time series models have been used. The first model will answer the question-Whether total provision increases with the increase in total loan and advances? The second model will answer- If total provision increases with the increase in total loan and advances, does the firm report more accrued interest income to protect the net profit? and does the firm increase other assets except accounts receivable for increase in accrued income where increase in other assets except accounts receivable with respect to increase in accrued income is an accounting treatment?

Model-1: $\operatorname{lnProv}_{t}=\beta_{0}+\beta_{1} \operatorname{lnTAE_{t}}+\beta_{2} \operatorname{lnOA_{t}}+\beta_{3} \operatorname{lnSI_{t}}+\varepsilon_{t} \ldots \ldots . .(M 1)$

Here, $\ln \operatorname{Prov}_{t}, \operatorname{lnTAE_{t}}, \operatorname{lnOA_{t}}, \operatorname{lnSI}_{t}$ are the natural logarithm of total loan loss provision, loan and advances, other assets except accounts receivable, and interest suspense account balance. $\beta_{1}, \beta_{2}, \beta_{3}$ represent the percentage change in provision for $1 \%$ change in loan and advances, other assets except accounts receivable, and interest suspense account balance respectively. In the first model natural logarithm of total loan loss provision has been used as dependent variable and natural logarithm of loan and advances, suspense interest account balance, and other assets as independent variables. All variables are used in logarithmic forms to get the high magnitude of goodness of fit since logarithm will give more importance to the small value and less importance to the large value. Another reason to express all variables in logarithmic forms is there is more likely that the relationship among variables will not be linear. It is a time series model. The model helps to find out the impact of increase in loan and advances and interest suspense account balance on total provision. Increase in provision decreases the bottom line (net income). As a result, the company may deliberately increase accruals to increase net profit. It is notable that increase in provision is the main reason for deliberately increase in net income.

\section{Model-2:}

$\ln A I_{t}=\beta_{0}+\beta_{1} \operatorname{lnTAE} E_{t}+\beta_{2} \operatorname{lnOA}_{t}+\beta_{3} \ln \mathrm{Prov}_{t}+\beta_{4} \ln F A_{t}+\beta_{5} \operatorname{lnOI_{t}}+\beta_{6} \ln S I_{t}+\varepsilon_{t} \ldots \ldots$ (M2)

Here $\ln A I_{t}, \ln O I_{t}, \ln F A_{t}$ are the natural logarithm of accrued interest and operating income. $\beta_{1}, \beta_{2}, \beta_{3}, \beta_{4}, \beta_{5}, \beta_{6}$ represent percentage change in accrued income for $1 \%$ change in loan and advances, other assets except accounts receivable, total loan loss provision, total fixed assets, operating income, and interest suspense account balance. In the second model natural logarithm of accrued interest has been used as dependent variable and natural logarithm of loan and advances, suspense interest account balance, other assets except accounts receivable, fixed assets, loan and advances, and operating income as independent variables. All variables are used in logarithmic forms to get the high magnitude of goodness of fit since logarithm will give more importance to the small value and less importance to the large value. Another reason to express all variables in logarithmic forms is there is more likely that the relationship among variables will not be linear. It is a time series model. The model helps to find out the impact of increase in loan loss provision and interest suspense account balance on accrued interest. Increase in provision and interest suspense decreases the bottom line (net income). As a result, the company may deliberately increase accruals to increase net profit. It is notable that increase in provision and interest suspense are the main reasons for deliberately increase in net income.

\subsection{Definition of the Variables Used in the Models}

\subsubsection{Total Loan Loss Provision $\left(\operatorname{Prov}_{t}\right)$}

In financial institution like banks and non-bank financial institution, majority of the total loan loss provision comes 
from classified loan. In financial institutions, loans are classified as- Substandard, Doubtful, and Bad and Loss. Non-bank financial institutions usually keep- 20\%, 50\%, and 100\% provision on Substandard, Doubtful, and Bad and Loss respectively. Also non-bank financial institutions in Bangladesh keep 1\% and 5\% provision on Standard and Special Mention Account loans. Provision has a direct impact on profitability of banks. The higher the provision, the lower the profit. The higher the non-performing loans (Sub-standard, Doubtful, and Bad and Loss), the higher the provision. Therefore, financial institutions always try to minimize the provision by minimizing the non-performing loans.

\subsubsection{Other Assets except Accounts Receivable $\left(O A_{t}\right)$}

Most of the financial institutions report a figure in balance sheet named as other assets. Sometimes financial intuitions can keep accounts receivable balance in other assets. It is notable that it is very tough to identify a portion of other assets. Therefore, there is a chance of overstatement of total assets via other assets figure or the portion of overstated accrued income can be kept in other assets except accounts receivable figure.

\subsubsection{Total loan and advances $\left(T A E_{t}\right)$}

Total loan and advances encompasses all the outstanding balance of the loan products for example, lease loan, term loan, real estate finance loan, work order finance loan, corporate finance loan etc. It is a key component of assets figure appeared in the balance sheet and it encompasses majority part of total assets.

\subsubsection{Interest Suspense Account Balance $\left(S I_{t}\right)$}

The suspended interest of classified loans or non-performing loans (Sub-standard, Doubtful, and Bad and LOSS) is transferred to interest suspense account balance. The higher the interest suspension, the lower the profit. Therefore, financial institutions try to boost up accrued interest figure to back up the increase in interest suspense.

\subsubsection{Accrued Interest $\left(A I_{t}\right)$}

It refers all the interest income accrued in a particular period of a financial institution. The higher the accrued interest income, the higher the profit. Therefore, financial institutions usually try to boost up the accrued interest figure to boost up their profit.

\subsubsection{Fixed Assets $\left(F A_{t}\right)$}

Fixed assets refer to property, plant, and equipment. This figure appears in the balance sheet. The size of the property, plant, and equipment is relatively for financial institutions than that of non-financial corporation. It is notable that fixed assets are not key revenue generating assets for financial companies.

\subsubsection{Operating Income $\left(O I_{t}\right)$}

Operating income figure appears in the income statement. It will come out after deducting operating expenses from total income. No extraordinary items would be adjusted with operating income.

\section{Analysis and Findings}

At first whether unit root problem exists or not in all the variables of suggested models- $\ln \operatorname{Prov}_{t}, \operatorname{lnTAE_{t}}, \operatorname{lnOA_{t}}, \ln S I_{t}, \ln F A_{t}, \ln F A_{t}$, and $\ln \mathrm{OI}_{t}$ would be checked. In the presence of unit root problem, application of OLS will give spurious results. To test unit root problem, a popular test, Augmented Dicky-Fuller test would be used.

5.1 ADF (Augmented Dicky-Fuller) Test

$$
\begin{gathered}
\Delta \varphi_{t}=\beta_{0}+\beta_{1} t+\delta \varphi_{t-1}+\sum_{h=1}^{k} \Delta \varphi_{t-h}+\varepsilon_{t} \ldots \ldots \ldots(a 1)(\text { with trend }) \\
\Delta \varphi_{t}=\beta_{0}+\delta \varphi_{t-1}+\sum_{h=1}^{k} \Delta \varphi_{t-h}+\varepsilon_{t} \ldots \ldots \ldots(a 2)(\text { without trend })
\end{gathered}
$$

Here, $\varphi_{t}=$ Variable under consideration for the test of unit root.

\subsection{Hypotheses under ADF Test}

$\boldsymbol{H}_{\mathbf{0}}: \delta=0$ (Unit root or Non - stationary)

$\boldsymbol{H}_{\boldsymbol{a}}: \delta<0$ (Stationary) 
Table1. Summary of ADF test result without difference form

\begin{tabular}{|c|c|c|c|}
\hline Variables & $\delta$ value (With trend) & $\delta$ value (Without trend) & Lag \\
\hline $\operatorname{lnProv}_{t}$ & $\begin{array}{l}-0.1836 \\
(0.1431)\end{array}$ & $\begin{array}{l}-0.1528^{*} \\
(0.0556)\end{array}$ & 1 \\
\hline $\ln T A E_{t}$ & $\begin{array}{l}-0.2656^{*} \\
(0.0713)\end{array}$ & $\begin{array}{l}-0.0475 \\
(0.6678)\end{array}$ & 1 \\
\hline $\ln O A_{t}$ & $\begin{array}{l}-0.0808 \\
(0.4348)\end{array}$ & $\begin{array}{l}-0.0702 \\
(0.2985)\end{array}$ & 1 \\
\hline $\ln A I_{t}$ & $\begin{array}{l}-0.3216^{* * *} \\
(0.0352)\end{array}$ & $\begin{array}{l}-0.3202^{* * * *} \\
(0.0067)\end{array}$ & 1 \\
\hline $\operatorname{lnOI} I_{t}$ & $\begin{array}{l}-0.5700^{* * * *} \\
(0.0000)\end{array}$ & $\begin{array}{l}-0.5371^{* * * *} \\
(0.0000)\end{array}$ & 1 \\
\hline $\ln F A_{t}$ & $\begin{array}{l}-0.1306 \\
(0.5003)\end{array}$ & $\begin{array}{l}-0.0432 \\
(0.2756)\end{array}$ & 1 \\
\hline $\ln S I_{t}$ & $\begin{array}{l}-0.4062^{\text {*** }} \\
(0.0020)\end{array}$ & $\begin{array}{l}-0.3601^{* * * *} \\
(0.0005)\end{array}$ & 1 \\
\hline
\end{tabular}

Note: ${ }^{* * *} \mathrm{P}<0.01$ denotes significant at $1 \%$ level, ${ }^{* *} \mathrm{P}<0.05$ denotes significant at $5 \%$ level, ${ }^{*} \mathrm{P}<0.10$ denotes significant at $10 \%$ level. The values under parentheses on the table refer the MacKinnon approximate Probability value. The lag has been selected by Akaike Information Criteria (AIC) and Bayesian Information criteria (BIC).

It can be said from the test result of Table 1 that the variables- $\ln P r o v_{t}, \ln T A E_{t}, \ln O A_{t}$, and $\ln F A_{t}$ are non-stationary whether the trend term has been included or not. The variables- $\ln A I_{t}, \ln S I_{t}$, and $\operatorname{lnOI} I_{t}$ are stationary at $5 \%$ significance level.

Now after taking the first difference of $\operatorname{lnProv}_{t}, \ln T A E_{t}, \ln O A_{t}$, and $\ln F A_{t}$, the ADF test results are given below:

Table 2. Summary of ADF test result with first difference form

\begin{tabular}{|c|c|c|c|}
\hline Variables & $\delta$ value (With trend) & $\delta$ value (Without trend) & Lag \\
\hline$\Delta \ln \operatorname{Prov}_{t}$ & $\begin{array}{l}-0.9377^{* * * *} \\
(0.0000)\end{array}$ & $\begin{array}{l}-0.9350^{* * * * 3} \\
(0.0000)\end{array}$ & 1 \\
\hline$\Delta \ln T A E_{t}$ & $\begin{array}{l}-1.0879^{* * * *} \\
(0.0000)\end{array}$ & $\begin{array}{l}-1.0865^{\text {**** }} \\
(0.0000)\end{array}$ & 1 \\
\hline$\Delta \ln O A_{t}$ & $\begin{array}{l}-1.1812^{* * * *} \\
(0.0000)\end{array}$ & $\begin{array}{l}-1.0963^{* * *} \\
(0.0000)\end{array}$ & 1 \\
\hline$\Delta \ln F A_{t}$ & $\begin{array}{l}-1.4137^{* * * *} \\
(0.0000)\end{array}$ & $\begin{array}{l}-1.3581^{* * * *} \\
(0.0000)\end{array}$ & 1 \\
\hline
\end{tabular}

Note: ${ }^{* * *} \mathrm{P}<0.01$ denotes significant at $1 \%$ level, ${ }^{* *} \mathrm{P}<0.05$ denotes significant at $5 \%$ level, ${ }^{*} \mathrm{P}<0.10$ denotes significant at $10 \%$ level. The values under parentheses on the table refer the MacKinnon approximate Probability value. The lag has been selected by Akaike Information Criteria (AIC) and Bayesian Information criteria (BIC).

It can be said from the test result of Table 2 that the variables- $\ln \operatorname{Prov}_{t}, \ln T A E_{t}, \ln O A_{t}$, and $\ln F A_{t}$ are stationary at the first difference form whether the trend term has been included or not. Therefore, the variables $-\ln \operatorname{Prov}_{t}, \ln T A E_{t}$, $\operatorname{lnOA_{t}}$, and $\operatorname{lnF} A_{t}$ are integrated at order one, I (1).

\subsection{Estimation of the Models}

At first the models have been estimated by using the OLS. After OLS, we have to prove that the models will satisfy all Gauss-Markov assumptions. The two key Gauss-Markov assumptions are- variance of the random error terms will remain constant (Homoscedasticity), $\operatorname{Var}\left(\varepsilon_{t}\right)=\sigma^{2}, \forall t$, and there is no relationship among the random error terms (serial correlation), $\operatorname{Cov}\left(\varepsilon_{t}, \varepsilon_{t-1}\right)=0, \forall t \neq t-1$. If the models fail to satisfy the assumption of homoscedasticity and no serial correlation, the GLS would be used to estimate the models. The other assumptions are- the mean of the random error terms will be zero $(0), E\left(\varepsilon_{t}\right)=0$, the random error terms will follow normal distribution (normality assumption), and there is no relation between explanatory variables and random error terms.

The estimation form of the first model will be (as only $\operatorname{lnSI}_{t}$ is stationary):

$$
\Delta \ln \operatorname{Prov}_{t}=\beta_{0}+\beta_{1} \Delta \operatorname{lnTAE} E_{t}+\beta_{2} \Delta \operatorname{lnOA} A_{t}+\beta_{3} \operatorname{lnSI}_{t}+\varepsilon_{t}
$$

In the first model after applying OLS, it has been observed that the $R^{2}=0.2069$ (only $20.69 \%$ of the $\Delta \ln P$ rov $v_{t}$ would be explained by the estimated regression equation, the model is significant at $5 \%$ level validated by the result of Joint test probality value $(<0.0004)$. The Adjusted $R^{2}=0.1768$. However, after testing heteroscedasticity by BreuschPegan test, variance of the random error terms is not homoscedastic $\left(\chi^{2}=57.69, P>\chi^{2}=0.0000\right.$, rejection of null hypothesis under constant variance). Therefore, the GLS method has been applied. From the GLS, it has been found that there is no heteroscedasticity, therefore the variance of the random error terms is homoscedastic $\left(\chi^{2}=0.71, P>\chi^{2}=0.4007\right.$, acceptance of null hypothesis under constant 
variance). After GLS, no serial correlation has been found also validated by Lagrange-Multiplier test (maximum 5 lags have been used where no auto-correlation is found at each lag). The distribution of the error terms has become normal validated by Shaprio-Wilk test. Also there is no relationship between explanatory variables and random error terms in GLS. The Variance Weighted Least Square (VWLS) has been used as a form of GLS where the absolute value of residuals from OLS has been used as variance for weighting. Under GLS, the value of $R^{2}=0.9197(91.97 \%$ value of $\Delta \ln \operatorname{Prov}_{t}$ would be explained by the estimated regression equation under GLS) and the value of Adjusted $R^{2}=$ 0.9156 . Also the model is significant which is validated by the Joint test probability value $(<0.0000)$. The summary of OLS and GLS results of model one has been given below:

Table 3. Summary of OLS and GLS results of model-1

\begin{tabular}{|c|c|c|}
\hline Variables & OLS result & GLS result \\
\hline$\Delta \ln T A E_{t}$ & $0.8803^{* * * *}$ & $0.8249^{* * * *}$ \\
\hline & $(0.0000)$ & $(0.0000)$ \\
\hline$\Delta \ln O A_{t}$ & $0.1452^{*}$ & $0.0978^{* * * *}$ \\
\hline & $(0.0690)$ & $(0.0000)$ \\
\hline $\ln S I_{t}$ & 0.0234 & $0.0218^{* * * *}$ \\
\hline & $(0.3370)$ & $(0.0000)$ \\
\hline Constant & -0.1145 & $-0.1052^{* * *}$ \\
\hline & $(0.3490)$ & $(0.0000)$ \\
\hline$R^{2}$ & 0.2029 & 0.9197 \\
\hline Joint Test P-value & 0.0004 & 0.0000 \\
\hline
\end{tabular}

Note: ${ }^{* * *} \mathrm{P}<0.01$ denotes significant at $1 \%$ level, ${ }^{* *} \mathrm{P}<0.05$ denotes significant at $5 \%$ level, ${ }^{*} \mathrm{P}<0.10$ denotes significant at $10 \%$ level. The values under parentheses on the table refer the Probability value.

As per GLS result (Table 3), it can be concluded that there is a positive impact of total loan and advances, other assets except accounts receivable, and suspended income account on total loan loss provision and the impact is significant at both $1 \%$ and $5 \%$ level. For $100 \%$ increase in the growth rate ${ }^{3}$ of total loan and advances and other assets except accounts receivable, the growth rate of provision would be increased by $82.49 \%$ and $9.78 \%$ respectively.

The estimation form of the second model will be (as only $\ln S I_{t}, \ln A I_{t}$, and $\ln O I_{t}$ are stationary):

$$
\ln A I_{t}=\beta_{0}+\beta_{1} \Delta \ln T A E_{t}+\beta_{2} \Delta \operatorname{lnOA_{t}}+\beta_{3} \Delta \ln \operatorname{Prov}_{t}+\beta_{4} \Delta \ln F A_{t}+\beta_{5} \operatorname{lnOI}_{t}+\beta_{6} \ln S I_{t}+\varepsilon_{t}
$$

In the second model after applying OLS, it has been observed that the $R^{2}=0.4015$ (only $40.15 \%$ of the $\ln A I_{t}$ would be explained by the estimated regression equation, the model is significant at $5 \%$ level validated by the result of Joint test probability value $(<0.0000)$. The Adjusted $R^{2}=0.3543$. However, after testing heteroscedasticity by BreuschPegan test, variance of the random error terms is homoscedastic ( $\chi^{2}=3.74, P>\chi^{2}=0.0532$, acceptance of null hypothesis under constant variance) but there exists serial correlation among the random error terms (validated by Lagrange multiplier test). Therefore, GLS has been applied. After application of GLS by estimating first order auto-correlation coefficient by Durbin Watson d-statistic, the test of heteroscedasticity has been applied again and no heteroscedasticity has been found but still auto-correlation exists. Therefore, again GLS has been applied by estimating first order auto-correlation coefficient from first attempt of GLS. After that again heteroscedasticity and auto-correlation have been checked. This time, no heteroscedasticity and auto-correlation have been found. The distribution of random error terms is normal checked by Shaprio-Wilk test. Also there is no correlation between explanatory variables and random error terms. The value of $R^{2}=0.2581$ ( $25.81 \%$ of the variation in $\ln A I_{t}$ would be explained by the fitted regression equation approximated by the GLS). The value of the Adjusted $R^{2}=0.1988$. The model is also significant validated by the Joint test probability value $(<0.0008)$. The summary of the OLS and GLS test results of model two is given below:

\footnotetext{
${ }^{3}$ Growth rate: $\triangle \ln T A E_{t}$ is actually the growth rate of loan and advances, where, $\triangle \ln T A E_{t}=$ $\ln T A E_{t}-\ln T A E_{t-1}=\ln \left(\frac{T A E_{t}}{T A E_{t-1}}\right)$. Similarly, $\triangle \ln O A_{t}$ and $\triangle \ln \operatorname{Prov}_{t}$ are the growth rates of
} other assets and total loan loss provision. 
Table 4. Summary of OLS and GLS results of model-2

\begin{tabular}{|c|c|c|}
\hline Variables & OLS result & GLS result \\
\hline$\Delta \ln T A E_{t}$ & 0.4453 & 0.3640 \\
\hline & $(0.1590)$ & $(0.2980)$ \\
\hline$\Delta \ln O A_{t}$ & $0.2015^{*}$ & 0.0719 \\
\hline & $(0.0560)$ & $(0.1470)$ \\
\hline$\Delta \operatorname{lnProv}_{t}$ & $0.2796^{*}$ & $0.1653^{* *}$ \\
\hline & $(0.0690)$ & $(0.0280)$ \\
\hline$\Delta \ln F A_{t}$ & 0.1628 & .04447 \\
\hline & $(0.5580)$ & $(0.7420)$ \\
\hline $\operatorname{lnOI} I_{t}$ & $0.1149^{* * * *}$ & $.04821^{* *}$ \\
\hline & $(0.0000)$ & $(0.0120)$ \\
\hline $\ln S I_{t}$ & $0.0782^{* * *}$ & $0.0785^{* *}$ \\
\hline & $(0.0220)$ & $(0.0410)$ \\
\hline Constant & $5.3082^{* * * *}$ & $2.2834^{* * * *}$ \\
\hline & $(0.0000)$ & $(0.0000)$ \\
\hline$R^{2}$ & 0.4015 & 0.2581 \\
\hline Joint Test P-value & 0.0000 & 0.0008 \\
\hline
\end{tabular}

Note: ${ }^{* * *} \mathrm{P}<0.01$ denotes significant at $1 \%$ level, ${ }^{* *} \mathrm{P}<0.05$ denotes significant at $5 \%$ level, ${ }^{*} \mathrm{P}<0.10$ denotes significant at $10 \%$ level. The values under parentheses on the table refer the Probability value.

As per GLS result (Table 4), total loan and advances, total other assets except account receivable, total loan loss provision, total fixed assets, total operating income, suspended income account have positive impact on the accrued interest income but only the impact of operating income, total loan loss provision, suspended income account is significant at 5\% level. For 100\% increase in operating income and suspended income accounts, accrued income would be increased by $11.49 \%$ and $7.82 \%$ respectively. For $100 \%$ increase in the growth rate of provision, the accrued interest income would be increased by $16.53 \%$.

It is notable that, there is no long-run relationship among the variables of both models.

\section{Conclusion}

It has been found that, increase in total loan and advances and interest suspense account balance increases the total loan loss provision. Increase in total loan loss provision and interest suspense increases accrued income. Increases in other assets except account receivable increases the accrued income but it is insignificant as per GLS result. It is very clear that more loan and advances are getting classified. It is not possible to have a positive relationship between interest suspense and accrued income. So, it can be concluded that the company is deliberately overstating accrued income to protect the consistency in the bottom line. It might be for the reason that the company has to fulfill a few demands of the stakeholders- the regulator (Bangladesh Bank as the regulator might penalize the company in terms of cancellation of its license), the share-holder, the depositors, and the bond-holders. Therefore, the regulators should develop more rigorous structures and systems to detect deliberate earnings management. The regulators should also closely monitor key financial variables namely total loan loss provision, net profit, interest suspense accounts balance and should through questions for more justification, accuracy, and reliability.

\section{References}

Ahmed, A. S., Takda, C., \& Thomas, S. (1999). Bank loan provisions: a reexamination of capital management, earnings management and signaling effects. Journal of Accounting and Economics, 28(1), 1-25.

https://doi.org/10.1016/S0165-4101(99)00017-8

Anandarajan, A., Hasan, I., \& Lozano-Vivas, A. (2005). Loan loss provision decisions: An empirical analysis of the Spanish depository institutions, Journal of International Accounting, Auditing and Taxation, 14, 55-77. https://doi.org/10.1016/j.intaccaudtax.2005.01.004

Anandarajan, A., Hasan, I., \& McCarthy, C. (2007).Use of loan loss provisions for capital, earnings management and signaling by Australian banks. Accounting and Finance, 47, 357-379. https://doi.org/10.1111/j.1467-629X.2007.00220.x

Arun \& Reaz (2005). Corporate governance in developing economies: perspective from the banking sector in Bangladesh. Development Economics and Public Policy Working Paper Series, Paper No. 14.

Barth, M. E., Landsman, W. R., \& Wahlen, J. M. (1995). Fair value accounting: Effects on banks' earnings volatility, regulatory capital and value of contractual cash flows. Journal of Banking and Finance, 19, 577-605. https://doi.org/10.1016/0378-4266(94)00141-O

Beatty, A., Chamberlain, S., \& Magliolo, J. (1995). Managing financial reports of commercial banks: The influence of 
taxes, regulatory capital, and earnings. Journal of Accounting Research, 33(2), 231-261. https://doi.org/10.2307/2491487

Beatty, A., Ke, B., \& Petroni, K. (2002). Earnings management to avoid earnings declines across publicly and privately held banks. The Accounting Review, 77, 547-570. https://doi.org/10.2308/accr.2002.77.3.547

Beaver, W., \& Engel, E. (1996). Discretionary behaviour with respect to allowances for loan losses and the behaviour of security prices.Journal of Accounting and Economics, 22, 177-206. https://doi.org/10.1016/S0165-4101(96)00428-4

Beaver, W., Eger, C., Ryan, S., \& Wolfson, M. (1989). Financial reporting, supplemental disclosures and bank share price. Journal of Accounting Research, 27, 157-178. https://doi.org/10.2307/2491230

Benston, G., \& Wall, L. (2005). How Should Banks Account for Loan Losses? Economic Review.Federal Reserve Bank of Atlanta.

Bhat, V. N. (1996). Banks and income smoothing: an empirical analysis. Applied Financial Economics, 6, 505-510. https://doi.org/10.1080/096031096333953

Bikker, J., \& Metzemakers P. (2005). Bank Provisioning Behavior and Procyclicality.Journal of International Financial Markets, Institutions and Money, 15, 141-157. https://doi.org/10.1016/j.intfin.2004.03.004

Bishop, L. (1996). Managing bank regulation through accruals. Working paper, New York University, New York.

Callao, S., \& Jarne, I. S. (2010). Have IFRS Affected Earnings Management in the European Union? Accounting in Europe, 7(2), 159-189. https://doi.org/10.1080/17449480.2010.511896

Collins, J., Shackelford, D., \& Wahlen, J. (1995). The coordination of regulatory capital, earnings, and taxes for banks. Journal of Accounting Research, 33, 263-292.

Craig, R., Davis, E., \& Pascual, A. (2006). Sources of procyclicality in East Asian financial systems.Procyclicality of Financial Systems in Asia, 55-123.

Davis, E., \& Zhu, H. (2009). Commercial property prices and bank performance.Quarterly Review of Economics and Finance, 49, 1341-1359. https://doi.org/10.1016/j.qref.2009.06.001

DeAngelo, E. L. (1986). Accounting Numbers as market Valuation Substitutes: A Study of Management Buyouts of Public Stockholders.The Accounting Review, 3, 400-422.

Dechow, P., Sloan, R., \& Sweeney, A. (1995). Detecting Earnings Management. The Accounting Review, 2, $193-225$.

Dugan, J. (2009). Loan Loss Provisioning and Pro-cyclicality.Remarks before the Institute of International Bankers.

Duru, K., \& Tsitinidis, A. (2013). Managerial Incentives and Earnings Management: An Empirical Examination of the Income Smoothing in the Nordic Banking. Department of Business Administration, Uppsala University.

Fama, E. (1980). Agency problems and the theory of the firm.Journal of Political Economy, 88(2), $288-307$. https://doi.org/10.1086/260866

Fama, E., \& Jensen, M. (1983). Separation of ownership and control.Journal of Law and Economics, 26, $301-325$. https://doi.org/10.1086/467037

Fan, L., \& Shaffer, S. (2004). Efficiency versus Risk in Large Domestic US Banks.Managerial Finance, 30 , 1-19. https://doi.org/10.1108/03074350410769245

Fonseca, A. R., \& Gonzalez, F. (2008). Cross-country determinants of bank income smoothing by managing loan-loss provisions. Journal of Banking and Finance, 32, 217-228. https://doi.org/10.1016/j.jbankfin.2007.02.012

Greenawalt, M., \& Sinkey, J. (1988). Bank loan loss provisions and the income smoothing hypothesis: An empirical analysis, 1976-1984, Journal of Financial Services Research, 1, 301-318. https://doi.org/10.1007/BF00235201

Healy, P. (1985). The effect of bonus schemes on accounting decisions.Journal of Accounting and Economics, 7(1-3), 85-107. https://doi.org/10.1016/0165-4101(85)90029-1

Healy, P. M., \& Wahlen, J. M. (1999). A review of the earnings management literature and its implications for standard setting.Accounting Horizons, 365-383. https://doi.org/10.2308/acch.1999.13.4.365

Jones, J. (1991). Earnings Management during Import Relief Investigations.Journal of Accounting Research, 29(2), 193-2001. https://doi.org/10.2307/2491047

Kanagaretnam, K., Lobo, G., \& Mathieu, R. (2004). Earnings Management to Reduce Earnings Variability: Evidence from Bank Loan Loss Provisions, Review of Accounting and Finance, 3(1), 128-148. 
https://doi.org/10.1108/eb043399

Kellogg, I., \& Kelogg, B., L. (1991). Fraud, Window Dressing, and Negligence in Financial Statements.Commercial Law Series, McGraw- Hill.

Kim, M., \& Kross, W. (1998).The impact of the 1989 change in bank capital standards on loan loss provisions and loan write-offs.Journal of Accounting and Economics, 25, 69-99. https://doi.org/10.1016/S0165-4101(98)00015-9

Kithinji, A. M. (2010). Credit Risk Management and Profitability of Commercial Banks in Kenya, School of Business, University of Nairobi, Nairobi.

Koch, T. W., \& Wall, L. D. (2000). The Use of Accruals to Manage Reported Earnings: Theory and Evidence. Working Paper Series, Federal Reserve Bank of Atlanta.

Kothari, S. P., Leone, A. J., \& Wasley, C. E. (2005). Performance matched discretionary accrual measures. Journal of Accounting and Economics, 39, 163-197. https://doi.org/10.1016/j.jacceco.2004.11.002

Laeven, L., \& Majnoni, G. (2003). Loan loss provisioning and economic slowdowns: Too much, too late? Journal of Financial Intermediation, 12, 178-197. https://doi.org/10.1016/S1042-9573(03)00016-0

Liu, C., \& Ryan, S. (2006). Income smoothing over the business cycle: changes in banks' coordinated management of provisions for loan losses and loan charge-offs from the pre-1990 bust to the 1990s boom. The Accounting Review, 81, 421-441. https://doi.org/10.2308/accr.2006.81.2.421

Ma, C. K. (1988). Loan loss reserves and income smoothing: The experience in the U.S. banking industry, Journal of Business Finance and Accounting, 15(4), 487-497. https://doi.org/10.1111/j.1468-5957.1988.tb00150.x

Meisel, S. I. (2013). Detecting Earnings Management in Bank Merger Targets Using an Industry Specific Model. Southern Business Review, 37(3), 1-20.

Moyer, S. (1990). Capital adequacy ratio regulations and accounting choices in commercial banks. Journal of Accounting and Economics, 13, 123-154. https://doi.org/10.1016/0165-4101(90)90027-2

National Association of Certified Fraud Examiners. (1993). Cooking the books: What every accountant should know about fraud. No. 92-5401. Self-study workbook: 12.

Peasnell, K. V., Pope, P. F., \& Young, S. (2000). Detecting earnings management using cross sectional abnormal accruals models, Accounting and Business Research, 30(4), 313-326. https://doi.org/10.1080/00014788.2000.9728949

Robb, W. G. (1998). The effect of analysts' forecasts on earnings management in financial institutions.Journal of financial Research, 21(3), 315-331.

Ronen, J., \& Yaari, V. (2008). Earnings Management: Emerging Insights in Theory, Practice, and Research, 3, New York: Springer.

Schipper, K. (1989). Commentary on earnings management.Accounting Horizons, 91-102.

Scholes, M, Wilson, P., \& Wolfson, M. (1990). Tax planning, regulatory capital planning, and financial reporting strategy for commercial banks. Review of Financial Studies, 3, 625-650. https://doi.org/10.1093/rfs/3.4.625

Tsai, D. H., \& Huang, F. W. (1999). Management Quality and Bank Efficiency: Empirical Evidence for Taiwanese Banks. Management Review, 18(3), 35-55.

Vatansever, M. \& Hepsen, A. (2013). Determining impacts on Non-Performing Loan Ratio in Turkey.Journal of Finance and Investment Analysis, 2(4).

Wahlen, J. (1994). The nature of information in commercial bank loan loss disclosures.The Accounting Review, 69, 455-478.

Wetmore, J. L., \& Brick, J. R. (1994). Loan loss provision of commercial banks and adequate disclosure: A note. Journal of Economics and Business, 46, 299-305. https://doi.org/10.1016/0148-6195(94)90040-X

\section{(cc) EY}

This work is licensed under a Creative Commons Attribution 3.0 License. 